\title{
Management of the dead in Tacloban City after Typhoon Haiyan
}

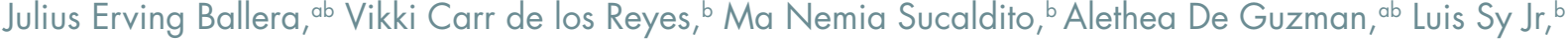 \\ Ma Justina Zapanta, ${ }^{b}$ Ferchito Avelino, Joselito Feliciano ${ }^{\mathrm{b}}$ and Enrique Tayag ${ }^{\mathrm{b}}$ \\ Correspondence to Julius Erving Ballera (email: jerving30@gmail.com).
}

Introduction: The post-disaster management of the dead involves a series of steps including on-site identification, transfer, storage and examination of bodies and delivery to families for burial. Two weeks after Typhoon Haiyan, a team from the Department of Health (DOH) was tasked with identifying the dead in Tacloban City.

Methods: A suitable site for the collection of bodies was identified and an algorithm and standard data collection form developed. The retrieval of bodies was coordinated with the Bureau of Fire Protection personnel. Upon receipt of a body, two team members conducted a systematic external examination. Findings were documented, photos were taken and each body was assigned a unique number.

Results: The DOH team examined 128 bodies. Of these, the majority (86\%) were complete bodies; $95 \%$ were decomposed and two were skeletonized. Two thirds (66\%) were adults, sex was identifiable for $92 \%$, and the male to female ratio was $1: 1.4$. The majority of adults were females. Only $11 \%$ were presumptively identified from documents in clothing; $89 \%$ remained unidentified.

Conclusion: From the limited setting of this study, we describe the process of rapid body processing post-Haiyan. We prioritized rapid processing over more technically complicated means of identification, including DNA testing. Our protocol showed a dignified and efficient way of identifying corpses. As local and regional laboratory capacity increases in the Philippines, the collection of DNA specimens may become part of the identification algorithm.

$\mathrm{T}$ he management of the dead after a disaster involves a series of activities that begin with the search for bodies, on-site identification of the body, transfer of the body to the facility serving as the morgue, delivery of the body to family members and assistance from the state for final disposal of the body. ${ }^{1}$ Management of the dead is one of the most difficult aspects of disaster response, as natural disasters, in particular, can cause a large number of deaths. ${ }^{2}$

Typhoon Haiyan was estimated by the National Disaster Risk Reduction and Management Council to have caused 6300 fatalities across the country. ${ }^{3}$ The Bureau of Fire Protection in Tacloban City was in charge of retrieving dead bodies which were originally placed in trenches in the public cemetery. There was no further system for managing these bodies. Although not a public health risk, the collection and disposal of bodies in this manner presented a psychologically traumatic experience for the affected population. ${ }^{4}$

Therefore, a team from the Department of Health $(\mathrm{DOH})$ was formed to assist with the management of bodies in Tacloban City post-Haiyan on 19 and 20 November 2013. This included the development of a body identification algorithm and data collection forms. This paper describes this experience.

\section{METHODS}

Upon arrival in Tacloban City, the $\mathrm{DOH}$ team assessed the public cemetery where the dead bodies had been placed. An alternate collection centre was identified, assessed and cleared by a sanitary engineer.

The DOH team developed an algorithm for managing the dead bodies based on the World Health Organization and $\mathrm{DOH}$ guidelines (Figure 1). ${ }^{1,5} \mathrm{~A}$ standard data collection form was also developed that included fields for physical description (body composition, decomposition status, sex and probable age) and evidence collected from the bodies.

The team coordinated with the Philippine National Police for security. City officials met with the community to prepare them for the transfer of bodies from the

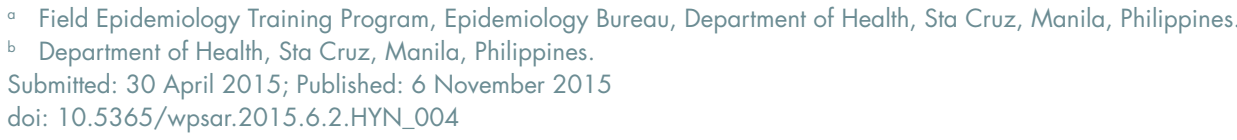


Figure 1. Department of Health's algorithm for the management of dead bodies after Typhoon Haiyan, the Philippines, 2013 ${ }^{1,5}$

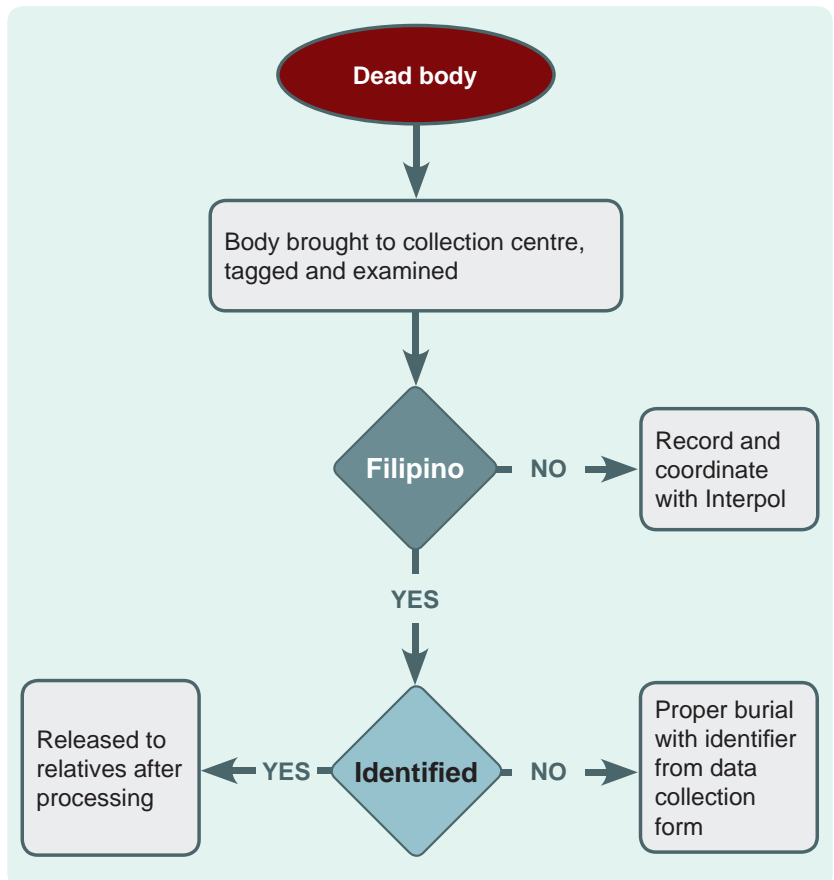

cemetery to the collection centre. At the collection centre the following tasks were conducted:

\section{Processing the dead bodies}

An area in the collection centre was identified to receive and place unexamined bodies along with any information obtained from the body. Upon receipt, each body was numbered, and pre-numbered tags were attached to the body and the body bag. Each body was then assigned to examiners and given a data collection form that was pre-numbered to match the body tag.

An area in the collection centre was designated for examination. The bodies were transferred from the receiving area to the examination area where at least two examiners were assigned per body to conduct a systematic examination. Findings were documented using the data collection form. An examiner also took photos of the body, clothing, accessories and other personal items. Each image included the body's unique number.

After examination, completed forms were collected and bodies were either released to the family or transferred to a holding area before burial.

\section{Burial}

The bodies without identification were buried in trenches proximal to the collection centre. Each trench was at least 1.5 metres deep, and the bodies were buried single file in the trenches. Wooden sticks with the relevant unique identification numbers marked the placement of bodies. A map of the buried bodies was created.

\section{Data storage, analysis and dissemination}

The data from the forms were entered on to a database and frequencies were calculated using Epi Info version 3.5.4.

\section{RESULTS}

From 20 to 21 November 2013, 256 bodies were received at the collection centre. Of these, $50 \%$ were processed by the $\mathrm{DOH}$ team; the remainder were processed by the National Bureau of Investigation. There was no common protocol for data collection on the bodies and no shared database.

Most of the 128 bodies examined by the $\mathrm{DOH}$ team were complete bodies (110, $86 \%)$; 95\% were decomposed and two were skeletonized. Sex was identifiable for 118 bodies (92\%) with a male to female ratio of $1: 1.36$. According to visual recognition of forensic experts, two thirds (66\%) were adults, $8 \%$ were adolescents, $20 \%$ were children and $5 \%$ were infants. The majority of the adult bodies identified were females (male to female ratio of $1: 1.5$ ). The non-adult sex ratio was 1:1 (Table 1 ).

Only 14 (11\%) of the bodies were identified through personal belongings contained inside the body bag; one other was identified by family members. Therefore, $89 \%$ remained unidentified and were buried accordingly. During the two days the team was present, none of these bodies were identified from the photographs of the deceased or their clothing.

\section{DISCUSSION}

The management of the dead was a major challenge in the aftermath of Typhoon Haiyan due to limited access to the affected areas. No identification was made for $89 \%$ of the bodies processed by the $\mathrm{DOH}$ team in Tacloban 
Table 1. Profile of bodies received at collection centre in Tacloban City, the Philippines, 20-21 November $2013(n=128)$

\begin{tabular}{|c|c|c|}
\hline Data & $N$ & $\%$ \\
\hline \multicolumn{3}{|l|}{ A. General body condition } \\
\hline Complete & 110 & 86.0 \\
\hline Incomplete & 9 & 7.0 \\
\hline Body part & 1 & 0.8 \\
\hline No data & 8 & 6.0 \\
\hline \multicolumn{3}{|l|}{ B. State of decomposition } \\
\hline Preserved & 0 & 0.0 \\
\hline Decomposed & 121 & 95.0 \\
\hline Skeletonized & 2 & 2.0 \\
\hline No data & 5 & 4.0 \\
\hline \multicolumn{3}{|l|}{ C. Sex } \\
\hline Male & 50 & 39.0 \\
\hline Female & 68 & 53.0 \\
\hline Probably male & 1 & 0.8 \\
\hline Probably female & 4 & 3.0 \\
\hline Undetermined & 1 & 0.8 \\
\hline No data & 4 & 3.0 \\
\hline \multicolumn{3}{|l|}{ D. Probable age group } \\
\hline Infant & 6 & 5.0 \\
\hline Child & 26 & 20.0 \\
\hline Adolescent & 10 & 8.0 \\
\hline Adult & 83 & 65.0 \\
\hline No data & 3 & 2.0 \\
\hline E. With names identified & 14 & 11.0 \\
\hline
\end{tabular}

City on 20 and 21 November 2013. Although visual recognition of cadavers is prone to errors, ${ }^{2}$ it is the simplest form of identification. It has been recommended that visual recognition should be complemented with other means of forensic identification, even if this occurs at a later stage. ${ }^{2}$ In this post-disaster setting, we prioritized rapid body processing over more technical means of identification such as DNA testing. We were also unable to determine if any bodies were identified from photos after we left.

In our study more female bodies were processed, consistent with a higher proportion of deaths reported from another study completed post-Haiyan. ${ }^{6}$ This finding is also consistent with data on deaths from a posttsunami study from Aceh, Indonesia. ${ }^{7}$ The total number of deaths from Typhoon Haiyan was estimated at 6300; however, this has not been disaggregated by age or $\operatorname{sex}^{3}$ so whether our results are representative is unknown. Generalizations about why females died are not always helpful in understanding complex and diverse processes. On the contrary, generalizations may create an image of females as vulnerable victims. ${ }^{7}$

For identification of the dead to be effective, a list of people missing and believed to be dead along with an organized collection of ante mortem data about those people would be useful. In the Philippines, a DNA database of citizens is not routinely done pre-disaster which limits the use of DNA references in identifying bodies after disasters.

A consequence of multiple agencies being involved in the management of the dead after Typhoon Haiyan was lack of a common database or identification algorithm. A well-coordinated system of managing dead bodies is an important factor in determining the postdisaster recovery speed of an affected community. ${ }^{8}$ The plan for the management of dead bodies is not exclusive to the health sector and requires previous planning and coordination with civil, governmental, military and police authorities at national and regional levels. ${ }^{9}$ This planning should be part of disaster preparedness.

The post-disaster management of the dead needs to be an efficient process, and a single protocol for identification and data collection should be established for use in future disasters in the Philippines. As local and regional laboratory capacity increases, collection of DNA specimens may be added to the identification algorithm, especially in disasters with a smaller number of deaths.

\section{Conflicts of interest}

None declared.

Funding

None.

\section{Acknowledgements}

We are grateful for the cooperation and support of DOH - Regional Office 8, the local government unit 
of Tacloban City, Dr Andres Patino of the International Committee of the Red Cross, Dr Raquel Fortun from the University of the Philippines and Dr Stephen Cordner.

\section{References}

1. Management of dead bodies in disaster situations: Disasters manuals and guidelines series, No 5. Washington, DC, Pan America Health Organization, 2004 (http://www.who.int/ hac/techguidance/management_of_dead_bodies.pdf, accessed 14 August 2015).

2. Morgan OP, Tidball-Binz M, van Alphen D, editors. Management of dead bodies after disasters: a field manual for first responders. Washington, DC, Pan America Health Organization, 2009 (https:// www.icrc.org/eng/assets/files/other/icrc-002-0880.pdf, accessed 14 August 2015).

3. NDRRMC updates re the effect on Typhoon Yolanda (Haiyan), 17 April 2014. Manila, Natural Disaster Risk Reduction and Management Council, 2014 (https://web.archive.org/ web/20141006091212/http://www.ndrrmc.gov.ph/attachments/ article/1 177/Update \%20Effects $\% 20 T Y \% 20 Y O L A N D A \% 20$ 17\%20April\%202014.pdf, accessed 14 August 2015)

4. Public health risk assessment and interventions, Typhoon Haiyan, Philippines $2^{\text {nd }}$ Edition - 16 December 2013. Manila, World Health Organization Regional Office in the Western Pacific, 2013 (http://www.wpro.who.int/philippines/typhoon_haiyan/ media/philippines typhoon haiyan ph risk assessment december2013.pdf, accessed $\overline{14}$ August $20 \overline{15}$ ).

5. Administrative Order No. 2007-0018: National policy on the management of the dead and the missing persons during emergencies and disasters (4 July 2007). Manila, Department of Health, 2007 (http://hems.doh.gov.ph/uploads/ policy_attachments/eb8c3af8ca141639f6b74c22712c5e9 7c8827736.pdf, accessed 14 August 2015).

6. Ching PK et al. An assessment of disaster-related mortality post-Haiyan in Tacloban City. Western Pacific Surveillance and Response Journal, 2015, 6(Suppl 1):34-38. doi:10.5365/ wpsar.2015.6.2.HYN_005

7. The tsunami's impact on women, Oxfam briefing note. London, Oxfam International, 2005 (http://policy-practice.oxfam.org.uk/ publications/the-tsunamis-impact-on-women-115038, accessed 14 August 2015).

8. Perera C, Briggs C. Management of dead in mass disasters - a review of South Asian perspectives. Kandalama, 2011 Annual International Conference - International Conference on Building Resilience, 2011 (http://www.iiirr.ucalgary.ca/files/iiirr/233.pdf, accessed 14 August 2015).

9. Risk of dead bodies associated with an epidemic. Washington, DC Pan America Health Organization, 2011 (http://www. paho.org/disasters/index.php?option=com content\&vie $\mathrm{W}=$ article $\& \mathrm{id}=971 \% 3$ Arisk-of-dead-bodies-associatedwith-an-epidemic\&catid $=1052 \% 3$ Amanagement-of-deadbodies\&Itemid=931\&lang=en, accessed 14 August 2015) 